\title{
Woman's work in the service of empire: Lady Margaret Field (1905-94) from school teacher to governor's wife
}

The presence of single and also of married British women in overseas colonies, especially those employed by or married to men in the Colonial Service in the later colonial period, has been the subject of scholarly enquiry. Their lives, roles and values and their distinctive contribution, if any, to the development of empire and of its ending have been debated. Their gendered roles were usually subordinate in a masculine culture of empire, and especially as wives they are commonly regarded as marginalised. The archived records left by Lady Margaret Field reveal her commitment as a single woman to a colonial mission and her sense of achievement as a school teacher and educational administrator, while also acknowledging the independence and career satisfactions she subsequently lost when she married a senior Colonial Service officer who rose to be a governor. But it is also apparent that though incorporated and subordinate as a governor's wife to her husband's career she was not marginalised to a separate sphere. As is evident from this case study, governors' wives had important and demanding political duties, and such responsibilities need to be acknowledged.

It is now some years since the conceptualisation of Britain's empire as an enterprise created and solely managed by white men and expressing the masculine values of the western male was first challenged. The presence of British women in overseas colonies is now more certainly recognised. Indeed, their functions as more than wives and mothers and their contribution to or complicity in the assertion of imperial values in hierarchies largely determined by race have been debated and are perhaps now better understood. ${ }^{1}$ A scholarly literature has also developed which considers whether and if so to what extent western women were liberated from conventional female careers and conventional feminine values and practices by life opportunities offered by empire. ${ }^{2}$ Particular attention has been given to those single women who largely late in empire embarked on professional careers especially in medicine and education. ${ }^{3}$ It has even been suggested that British women as teachers in the Colonial Empire had a wider political agenda or at least a wider political effect than classroom learning, namely liberating indigenous women in local cultures from traditional values and roles. ${ }^{4}$ Even so, those married to men in the Colonial Service are often still marginalised as incorporated wives, ${ }^{5}$ their lives 'vacuous and superficial' and subordinate to the careers of their husbands, their functions feminine, and therefore by implication historically secondary in significance and consequence.

In this context the sequentially contrasting careers in the Colonial Empire of Margaret Field, née Judd, make her life worth particular consideration. She was born in Glasgow on 14 July 1905, but raised largely in London. Then in 1928 she was appointed as secretary to the principal of Achimota College in the Gold Coast. After an interim period back in London, she spent most of the rest of her life overseas in the Colonial Empire. For ten years from 1937 she was a teacher in Northern Nigeria. Then in 1947, still a single woman, she was appointed to a senior administrative post and served for four years as registrar in Nigeria's Education Department. However, in Lagos in January 1951 Margaret Judd (aged 45) married John Field (aged 37). Thereafter she served empire no longer as an independent professional woman but as the wife of a senior colonial serviceman and in due course as Lady Field, wife of Governor Sir John Field. John Field was born in Portsmouth on 30 October 1913 but 
raised largely in Natal. After taking a degree at Cambridge he joined the Colonial Service in 1936 as an administrative cadet in Nigeria. He rose to become Commissioner of the Southern Cameroons in 1956, Governor of St Helena in 1962, liaison officer based in London for Her Majesty's Colonial and Overseas Service (HMCOS) in 1968, Acting Administrator of Montserrat in 1969, and finally from January 1970 (by when of course few formally governed colonies of the British Empire remained) Resident Commissioner in and from January 1972 Governor of the Gilbert and Ellice Islands Colony after its separation from the Western Pacific High Commission. Sir John Field and Lady Field retired in April 1973, and lived in Himeville, Natal until his death on 22 February 1985. Thereafter she returned to the UK, where she died on 12 May $1994 .^{6}$

Still too few studies have explored the careers of British women who saw appealing opportunities in the Colonial Empire, including especially in the Colonial Service. ${ }^{7}$ This is surprising since Partners in Progress, the book written by Sir Charles Jeffries, deputy undersecretary of state at the Colonial Office, and published in 1949 carried as its sub-title The Men and Women of the Colonial Service. One chapter, 'Women of the Colonial Service', records that between 1922 and 1943, 83 women had been recruited for educational posts, 72 for medical posts, 8 for 'miscellaneous posts' and as many as 2189 as nursing sisters. Certainly to encourage further applications and no doubt to address expectations raised by the 1940 and 1945 Colonial Development and Welfare Acts, Jeffries records that already in the two post-war years, and in addition to an unspecified number of nurses, 200 other women had been recruited. These included 90 appointments to educational posts plus others to be engaged broadly in social welfare work, including posts needing scientific or other qualifications. ${ }^{8}$ What he was implying, as an appeal, was the contribution to empire which women might make within a professionalised Colonial Service. In 1999 Kirk-Greene in his history of what in 1954 became HMCOS continued the numerical history, showing that from 1942 to 1952 a total of 2512 women had been appointed to the Colonial Service (2185 from 1945). As before, most were nurses, 1603, followed by 717 appointed to education posts, and the remainder, 192, were doctors, administrative assistants and unspecified others. To put those figures into perspective, total Colonial Service recruitment from 1942 to 1952 amounted to 10,945 , and total strength had reached around 18,000 by 1954 . By 1960 , HMCOS officers numbered 20,500. ${ }^{9}$ Obviously, while increasing numerically, women in the Service remained a minority. Moreover and also obviously, recruiting figures in themselves do not tell us about the pattern of women's careers. It should be noted by way of introduction to what follows that Jeffries also praises the contribution made by the wives of colonial servicemen to the colonial enterprise, not only in providing 'wifely support for their husbands' but also voluntarily as in effect unpaid social workers. ${ }^{10}$

Because of the gender imbalance it follows that while the number of published memoirs by former Colonial Service personnel is substantial, most accounts are by men. An annotated on-line list records 358 written by men, and only 55 by women. ${ }^{11}$ Moreover, 42 of those women went overseas because they had married men in the Colonial Service. The overseas professional careers of four others were disrupted when they subsequently married. That leaves just nine who continued with their professional lives uninterrupted, mainly in education, medicine and latterly in administration. Only one of the nine was married and yet able to continue her career, as an entomologist, working with her husband. ${ }^{12}$ Moreover, of all these 55 memoirs, only seven were written by women who by marriage were elevated to become the wives of colonial governors or men of comparable rank, and of these probably only two had previously had independent careers: Lady Maddocks, a secretary and then briefly a medical librarian, and Lady Sharwood-Smith, for three years a physiotherapist. ${ }^{13}$ 
We also have oral evidence. At a Witness Seminar organised in 2015 by the Institute of Commonwealth Studies in conjunction with the Overseas Service Pensioners' Association, it was acknowledged that 87 men but only nine women had given testimony at the previous nine sessions, an imbalance which the 2015 seminar with only women contributors set out to adjust. The sixteen personal histories provided formally or described in discussion suggest that four of the women had not been in paid careers either before or after getting married and going overseas, and the careers of four other women had ended when they married. On the other hand, even though certainly six of them had married, eight women had sustained their careers overseas, five in education, one a nurse, one an executive officer in the Hong Kong police, and one a tax officer and also later a special constable. It should however be noted that the careers of only two witnesses (presented by descendants) began before the Second World War; and several of the others were launched in late empire days by when more job opportunities for women had opened up. ${ }^{14}$

Also available are the career histories of women who served overseas which were collected by the Oxford Development Records Project, profitably used by Helen Callaway. Other reports based on personal testimony provide additional opportunities to better understand the roles and experiences of women who served specifically as administrative officers, nursing sisters - and as wives. ${ }^{15}$ These last include thirteen women who had married men who became colonial governors. Only four of these governors' wives seem previously to have become professionally qualified and to have had independent careers as single women (and probably only in the UK), and these ended when they married into the Colonial Service and went overseas. Two of them have been referred to above, Lady Maddocks and Lady SharwoodSmith, the others being Lady Luddington, formerly a nurse, and Mrs Sylvester Smith, previously a schoolteacher and latterly a deputy head.

While reference will be made to these complementary sources, much use will be made in this essay of the Field Papers which Lady Field donated to Oxford's Bodleian Library. ${ }^{16}$ This substantial collection includes letters Margaret Judd wrote from Nigeria to family and friends between November 1937 and January 1939 when she was a single woman. ${ }^{17}$ These are followed, after her marriage in 1951, by Margaret Field's private diaries, running with some interruptions from February 1953 to December 1973. Occasionally they incorporate copies of letters to friends and family kept in lieu of diary entries. ${ }^{18}$ In addition she left photographs and other material generated during her career. In retirement and drawing largely on these records, Lady Field drafted her unpublished memoirs, completed in 1988 when she was 82. It runs to nearly 600 typescript pages and is entitled (reasonably enough, as will be seen) 'Not a Life of Leisure'. ${ }^{19}$ This is of course a retrospectively constructed narrative and interpretation of her own life, and written after the formal ending of Britain's Colonial Empire had largely been completed. Therein she represents herself as a successful and public figure who, after a hesitant start, embarked overseas on a legitimate mission in empire, first as an educator and then as the wife of a man who became a governor. It is her representation of the challenges she faced, the work she did, and her sense of worth and achievement which merit attention. Her donation also includes the journals written by John Field, and these too are of value in illuminating her career. The surviving volumes (others he had destroyed) cover the years 1935-41 before they met and married, and then from September 1962, when he was governor of St Helena, to May 1974, when he retired as Governor of the Gilbert and Ellice Islands. ${ }^{20}$ One day in 1963 in answer to Margaret Field's inquiry about what he wrote in his journal, John said he recorded what he had done that day; Margaret told him that she wrote down what she was feeling or thinking, and this is also often true of her letters. ${ }^{21}$ Their 
confessional character and her memoirs reveal the constraints and dissatisfactions endured by a woman who in the late colonial period, after a successful and independent overseas career, had hitched her life to an ambitious Colonial Service officer, but also the important political duties she acquired by marriage and performed in the service of empire.

The intention of this essay is therefore to contribute to the existing scholarship on the roles and experiences of women in the Colonial Empire by first exploring the experiences of Margaret Judd in the late 1930s and 1940s as an independent career woman - a teacher and then a senior administrator - taking appropriate note of how she represents herself in the sources she subsequently deposited. These were years in which the education of girls in Nigeria was intended by the Colonial Office to have a beneficially transformative effect on their lives and subsequently as wives and mothers on African society more generally. ${ }^{22}$ Then, following her marriage in 1951 and her elevation in status, she operated as an incorporated wife, in the sense that her geographical relocations were determined by her husband's career trajectory and her specific duties derived from her status as his wife. John Field had acquired through his career progression and his intimacy with higher ranking officers, and their wives, a clear sense of what was expected not only of himself but of his wife, but those standards had also been impressed upon Margaret Judd in her own pre-marital contacts with those higher in the colonial hierarchy, and they were reinforced on marrying John. ${ }^{23}$ As a result, by incorporation in a role subordinate to but supportive of John Field's career, Margaret Field remained an agent of empire. She had for her husband, and for the organisation he served, a 'resource value'. But since she did not record it that way, it would be misleading to depict her as operating in a 'separate sphere' disconnected from the serious work of her husband. ${ }^{24}$ His and her journals and her memoirs abundantly demonstrate their shared domesticity and his contribution to its creation and functioning; but both also occupied and performed roles in public spaces, which included, as we will see, their official homes. Moreover and importantly, while their specific roles were certainly different, and hers obviously secondary to his, the narrative she constructed from her records depicts and legitimises her working life, as well as his, as being essentially political, both of them equally concerned with the management, development and future of empire.

\section{II}

To appreciate the gendered roles she performed and the effect on her of what she herself described as a 'very late marriage', ${ }^{25}$ it is first necessary to know more about her upbringing, education and her previous career as a single woman, and indeed something of her personality and former private life. Margaret Judd was born into a financially secure family of high social status. Her father, Harold Godfrey Judd (1878-1961), had become a senior partner in a successful firm of chartered accountants. He was also employed by the Ministry of Munitions in the First World War, being awarded a CBE for his services. In the Second World War he was appointed Controller and then Director of Salvage, and he was Mayor of Hampstead 1951-53. ${ }^{26}$ The family had moved from Glasgow to London and settled in the upper middle class enclave of Hampstead Garden Suburb in 1915, and - important for her future expectations - the young Miss Judd became used to having the support of domestic servants. Her education was unusual but not unique for someone of her social class at that time, initially being tutored at home by her Froebel-trained mother, before being sent aged 12 or so to a day school in Hampstead and then aged 14 to a boarding school, where, most likely, she became grounded in the skills of independent living within a controlled environment. However, less commonly, after leaving school aged 17 she attended Bedford College, which had become a constituent part of London University in 1900 with a record of 
supporting women's advancement in public life. She chose to study only for a Pass degree, in Arts, but she retained a life-long commitment to learning. She became an avid and critical reader, fluent in French and German (and later in Hausa, though she seems to have stumbled when trying to learn Gilbertese), and her diaries, memoirs and some published pieces show gifts as a writer and also her knowledge of the arts and her sensitivity to the natural world. ${ }^{27}$ Also she had a personality which attracted the lasting friendship and loyalty of women, and more than the admiration of men. With respect to her career, more immediately helpful were the shorthand and typing skills she acquired after university at a secretarial college. ${ }^{28}$

Her origins and education do not alone account for her stepping into Africa. As was common among women as well as men who were attracted by empire, Margaret Judd's family had a history of careers overseas. Grandparents on her father's side had both been members of the Church Missionary Society, and indeed her father had been born, educated and lived in China until he was 16. At least one of her uncles remained in China, and another (possibly from her mother's side) was in the Gold Coast medical service before and then after the First World War and in the Cameroons during the war years. ${ }^{29}$ Employment in empire was not exceptional for an unattached single woman of her social class, with such family associations, educational background and skill set, ${ }^{30}$ but her father had also been honorary accountant of the International African Institute since $1926,{ }^{31}$ and it was his connections which secured her appointment in 1928, aged 23, as secretary to Rev Alexander Garden Fraser, the founding principal of Achimota College. ${ }^{32}$ Young, self-confident, attractive and evidently flirtatious, it appears that she not only fell in love with Africa but with a man she met on the ship and then, with unhappy results, with the bursar at the college, an affair with a married man which probably led to the termination of her contract in 1930. She recovered from this rather serious setback, personally and in terms of the career of a single woman at that time, by finding a job working in Selfridge's Information Bureau, surrounded by reference books and responding like an off-line Wikipedia to client inquiries. From there she was rescued again by her father's contacts and was eventually appointed as secretary to the personal assistant of Lord Hailey who was then working at Chatham House on his magisterial African Survey. Not only did this restore a connection with Africa, but it generated another close friendship with women (all Europeans) upon whom as confidantes, in addition to her younger sister Diana, she was to depend later in life, especially when as a governor's wife, as others in her position later recorded, she found it more difficult to form such relationships with other women lower in the colonial hierarchy. ${ }^{33}$ More immediately important, working on the African Survey prompted a re-launch of her career in empire. ${ }^{34}$ Encouraged by Olive Robinson, a single woman with whom she had struck up a life-time friendship in Achimota and who also went on to teach in Northern Nigeria, ${ }^{35}$ she contacted Hanns Vischer, a member of the Colonial Office's Advisory Committee on Native Education in Tropical Africa and former Director of Education in Northern Nigeria. ${ }^{36}$ On his advice Margaret Judd took a postgraduate diploma course at the Institute of Education, University of London, and prepared herself for teaching overseas. Then, in November 1937, aged 32, she began her career in education in Nigeria which only ended in 1951 when she married John Field. Before that, she later wrote, 'I had my own career... and on the whole a marvellously lucky and happy life'. ${ }^{37}$

There is a lyricism in the letters she wrote home about her experiences in the late 1930s, recaptured and extended into the 1940s in her retrospective memoirs. ${ }^{38}$ They express the stimulating effect upon her of encountering the Muslim people of up-country Northern Nigeria, of the landscape and natural world of Birnin Kebbi and Sokoto province, of the joys (as well as tribulations) of setting up a home of her own in a government house, of the 
appointing and training and quality of her servants, of her garden, of learning Hausa, of coping with illness, of her exploration of the region in the car with which her generous father had provided her, of parties, conversation, horse-riding, canoe trips, bird life, the scents and sunsets, and the friendship of women colleagues - and of lovers and a broken engagement. ${ }^{39}$ More importantly for our purposes, in her letters and also retrospectively and uncritically in her memoirs, she also writes enthusiastically of being a single woman committed to a career in which she believed and found rewarding. Educational provision by colonial governments, especially for girls and particularly for Muslim girls in Northern Nigeria, was a recent development. ${ }^{40}$ The school to which she was assigned had only recently been established, by her friend Miss Olive Robinson, and Miss Judd was taking over from her successor, Miss Wainwright. Margaret Judd sums up a commitment all three probably shared. Struck by what she saw as 'dreadfully primitive people', she was at once convinced that, 'as a beginning', hers was a 'job that needs doing'. ${ }^{41}$ The school accommodated forty girls aged 5 to 15 , and her duties included teaching the 'three Rs' plus hygiene, baby care and other domestic skills, as well as organising meals and medical treatment and supervising her Nigerian women assistants. The school had been set up with the support of the local emir and was locally welcomed, perhaps because of the domestic welfare skills the girls were learning. In conformity with a convention common at elementary schools in Northern Nigeria, the language of instruction was that used locally, not English. Hence the need for Miss Judd to learn Hausa. ${ }^{42}$

In December 1938 she wrote candidly to a friend about her experiences after a year in Birnin Kebbi. ${ }^{43}$ She was enjoying her role as a teacher and especially as an organiser, and was pleased to have received a very good official report on her work. She also liked the children and believed that local people appreciated her work. But the real satisfaction came from doing what she believed was necessary, 'even vital to the country, for the general standard of living, of health and cleanliness and education is deplorable'. Miss Judd had an ambitious agenda. She was certain that local girls needed to be properly trained as teachers to end the reliance on teaching by European women. Indeed, she stressed what was in effect a political and specifically colonial feminist agenda - that standards 'can't be raised much unless the women are helped, and can improve their homes, and help the country by being nurses, teachers, etc'. Here indeed was a mission statement, still with the emphasis on welfare but also aiming to provide Muslim girls with opportunities to make a difference by following western career models. But self-evidently this was particularly and conventionally feminine, a woman training girls in the domestic responsibilities of women. ${ }^{44}$ It may be that some girls so trained became agitators for political change, but there is no indication that Miss Judd intended to leave such a legacy. ${ }^{45}$ Certainly, in her memoirs, she does not refer to any such consequences either as an achievement or as a regret.

The early age at which Muslim girls were conventionally married was an obstacle. ${ }^{46}$ Hence in letters and memoirs her strongly expressed sense of achievement when this 'long tradition' was broken. The local emir agreed that girls should no longer be expected to marry young and certainly by the age of 14 , so that some could therefore be trained as primary school teachers at a new Women's Training Centre in Sokoto. This was to be a boarding school for girls in Nigeria's northern provinces for, as Margaret Judd wrote at the time, 'without more trained teachers...how can this education business go on at all?" ${ }^{47}$ Such, evidently, was the impression made on colonial administrators by her zeal that in 1939 she was appointed as a teacher at the college, and in 1943 she was further advanced to become its principal. In her memoirs she wrote, without a hint of reservation, that the girls were recruited 'by persuasion and pressure', although a later principal was shocked by what she saw as enforced enrolment 
and the distress it caused. Narrators tell different stories, and Lady Field in retirement presented a narrative of achievement, while acknowledging the difficulties of teaching unwilling pupils who only wanted to get married. ${ }^{48}$ Her next step up, in 1947 after eight years in Sokoto and now aged 42, she accepted with some reluctance since it took her away from college life. She was promoted to a higher grade and made registrar responsible for examinations and scholarships for the whole of Nigeria and for managing a staff of twentytwo clerks, initially in Enugu and then from 1948 in Lagos. It was, she recollected, 'quite a big thing'. This was a post she was to hold until she married. ${ }^{49}$ In 1938 Margaret Judd had written to a woman friend about her teaching: 'I do intend to go on with it, for at least some years, if I do not marry' ${ }^{50}$ But then she met and, seemingly to her astonishment, fell 'deep in love' with John Field. ${ }^{51}$

It is not difficult to imagine what her life might have been had she stayed single and continued her career in teaching or in educational administration in West Africa or wherever else in late empire better schooling was seen as essential for political as well as economic and cultural development. Post-war the demand for teachers in colonial and newly independent territories was exceptionally large, and unsatisfied. While many were appointed by churches and the British Council, those recruited by HMCOS alone totalled 463 women (and 752 men) between 1957 and 1961. ${ }^{52}$ Or indeed Miss Judd might have continued in educational administration, like Miss Gladys Plummer, who became Deputy Director of Education (Women) in Nigeria, 'a real friend' with whom she had worked for a while. ${ }^{53}$ Or Miss Judd might have been recalled to London, as a practised administrator with fieldwork experience, to serve in the education department at the Colonial Office or its successors, probably with responsibilities for the education of girls, like Miss Freda Gwilliam with whom the Fields later became acquainted, a single woman and former teacher who had been appointed as the Colonial Office's first women's educational adviser in $1947 ;{ }^{54}$ or Miss Jean Deas, a Foreign and Commonwealth Office adviser on women's education, with whom at Tarawa in the Gilbert Islands in March 1971 Margaret had a conversation which evidently connected with her own former professional experiences: 'She is shrewd and full of ideas and we found plenty to talk about'. ${ }^{55}$ Nor was marriage necessarily incompatible with a successful professional career. ${ }^{56}$ The number of women and especially married women employed in the higher professions and management was still disproportionately low in post-war Britain, but numerically rising, and it was noticed in 1961 that the level of education and professional skill among English-born women living overseas was on average significantly superior to the female population at home. ${ }^{57}$ There were then independent careers in the UK and in the wider world which a single woman with Miss Margaret Judd's background could have developed. From the late 1950s, in the ebbing years of formal empire, these might also have been available to Mrs Margaret Field. But such possibilities were inconceivable for a governor's wife - like Lady Margaret Field.

\section{III}

Her diaries and memoirs suggest that Margaret and John Field had a loving and durable relationship, and a companionable if not companionate marriage. Nevertheless, with her personality, her previously liberated private life, her independent career experience, her accumulated skills and expertise, and her age on marriage, it is not surprising that there were times, reported in diaries and in memoirs, when she struggled to adapt as the wife of a senior Colonial Service officer. She does not record the fact, but she would have been obliged by Colonial Service regulations current when she married to resign from her post. ${ }^{58}$ During and immediately after the war with so many men in the armed services, colonial administrations 
had employed the wives of some Colonial Service men, but usually as temporary staff and in low grade clerical posts. Even thereafter women administrative officers were required to resign on marriage and if re-hired their terms of service were less attractive. Only by the late 1950s did opportunities for married women to retain or secure paid employment somewhat increase when, with the localisation of administration in preparation for decolonisation, fewer men were joining the Colonial Service and more were leaving. ${ }^{59}$

In Margaret Field's case, keeping her job was not an option, and in any case her husband would not have approved. Once only after they were married, with John's consent and to her delight, did she teach again - European children in her own home in Ikoyi, the area of Lagos where largely white families lived: 'That school was one of the happiest and perhaps one of the best things I have ever done'. This limited revival of her unincorporated life flickered out when John Field went on leave, and Margaret went with him. ${ }^{60}$ Sometime later, back in Lagos, she again went out to work, mornings only, as secretary to a large timber business, but this time only with her husband's reluctant agreement. As an expression of masculine gendered authority, his attitude needs to be remembered: 'He did not think it altogether suitable that I should do a paid job at all'. But her memoirs buzz with her delight in again using her administrative skills and being independently busy. This episode too closed when they next went on leave. ${ }^{61}$ Only occasionally thereafter and only in her capacity as the governor's wife did she enter a school and assess, with a lingering professional eye, the quality of the teaching, the teachers and the pupils. ${ }^{62}$

There was another regret to which she repeatedly referred. Margaret Field's three sisters and her brother all married and had children. Prompted by meeting other people's children, particularly girls, she wished that she too had had a daughter, but that had probably not been possible (except by adoption) because of her previous career as a single woman, her earlier broken relationships, and her late marriage. ${ }^{63}$ But being childfree spared her the predicament of separation from husband or from child, which even in late empire was an issue with which Colonial Service wives in some stations still struggled, especially with respect to children's education. ${ }^{64}$ From the institutional viewpoint of colonial rule it also meant that she was not distracted by family from her role as governor's wife, and the compensation for Margaret Field was that she was rarely separated from her husband, whether on tours when in post or when travelling during their extended periods of paid leave.

During their time together, John Field's workload included involvement in the constitutional deliberations leading to the independence of Nigeria in 1960 and to a territory-wide plebiscite to determine the political destiny of the Southern Cameroons in 1961. In St Helena, 1962-68, he had to cope with the near collapse of the island's economy, to try and improve poor welfare services with limited resources, and to hold at his own insistence the island's first general election, necessary in his view to make islanders more responsible for their own future. ${ }^{65}$ When temporarily relocated with Margaret in London in 1968-69, he was endeavouring to address the career concerns of HMCOS staff in a shrinking formal empire. ${ }^{66}$ Then in Montserrat later in 1969, he had to tackle the emergency caused by the chronic illhealth and doubtful policies of a governor suddenly gone sick. ${ }^{67}$ Finally, in the Gilbert and Ellice Islands, 1970-73, when self-government was seriously on the agenda, he struggled with the constitutional and administrative complexities of governing islands scattered over two million square miles of ocean and divided by ethnicity and conflicting political aspirations. ${ }^{68}$ 
Margaret Field's diaries and her memoirs refer to some of these matters, but briefly, and especially when she noted that her husband was working too hard and looked weary. 'I heard a certain amount about John's work', she wrote later with a tone of regret, 'but not as much as I would have liked. ${ }^{69}$ On one occasion he refused to reveal what was troubling him because the security matters with which he was concerned were not only top secret but too 'frightening' to tell her. ${ }^{70}$ True, in Montserrat and in Tarawa in the Gilbert Islands, he did sometimes discuss administrative problems with her, and, as she recorded in her diary, 'I do like that'. ${ }^{71}$ She later recorded in her memoirs, rather wistfully, that 'I never fully accepted the fact that all women with husbands dedicated to important work must accept - that the work must come first'. ${ }^{72}$ Indeed, at the time, she criticised herself bitterly for not having consistently followed the patronising advice offered to her by one of John Field's senior colleagues early in their marriage: 'Don't stop him working'. ${ }^{73}$

Colonial Service officers who did acknowledge the important role played by their wives were not (usually) acknowledging only the creature comforts secured by having at home a live-in partner. ${ }^{74}$ Other governors, we know, were far more willing to discuss their work with their wives and to draw on their separately acquired local knowledge, their advice and their practical assistance. ${ }^{75}$ This also seems to have characterised many of the relationships between senior figures and their wives in the Anglo-Indian community in British India. ${ }^{76}$ But while John Field seems to have been less willing than other senior officers to consult his wife, this did not mean that the political value of Margaret Field, or of other wives similarly placed, was marginal. There were of course unmarried governors in the Colonial Service, and single status was not a bar to promotion, but the absence of a suitable wife perhaps explains why one senior official in London complained that some of the later problems in St Helena following the departure of Sir John and Lady Field were because 'we've had 10 years of fuddy-duddy bachelor governors' ${ }^{77}$ Indeed, the Colonial Office and its successors generally favoured in effect a 'buy one get one free' policy. John Field himself described the wives of senior colonial officials as 'unpaid civil servants'. ${ }^{78}$

\section{IV}

It is important not to underestimate the political importance of public performance in the management of the Colonial Empire. However much (or little) colonial authority was underpinned by military force, the legitimacy, status and authority of colonial rule also depended considerably on how effectively governors visibly operated as representatives of the Crown in colonised territories. ${ }^{79}$ Such obligations also devolved upon their wives. Of course, Lady Margaret Field was the consort not the lead figure. Her roles were secondary to and supportive of Sir John's, but public ceremony was regularly part of their joint lives, and duly recorded in her memoirs. This was most obvious when arriving together to take up new posts, when standing together while Sir John received the royal salute, when being greeted on tour around their territories, when departing on and returning from leave, when welcoming important (including royal) visitors, when attending Remembrance Day services and other ceremonial events, and when bidding farewell having completed terms of office. ${ }^{80}$ Usually, Lady Margaret also attended Sunday church services with Sir John, accepted pretty much as another joint obligation of the post. (It was not something they routinely did when on leave.) These were all occasions when the governor represented not himself but the Crown, and hence the formality of dress of the governor - and of his wife.

A consequent obligation placed upon the residents of Government House, which were in effect 'tied cottages', was to be good hosts. Formal dinners and receptions were political 
occasions, but in their preparation and performance inevitably gendered. For governors' wives, 'their role as hostess was part of their husband's job' ${ }^{81}$ When John Field was being considered in the Colonial Office as the next governor of St Helena it was noted to his credit that the Fields 'entertain well'. ${ }^{82}$ Hospitality on the lines expected was rarely a matter of a couple of beers over a relaxing lunch with colleagues or visiting family. On the contrary, invitations to attend dinners and larger gatherings at the home of a governor and his wife carried considerable weight. They removed by design the boundary between their private sphere and the public. ${ }^{83}$ Those invited by the Fields into their domestic space commonly included representatives of the local community, as well as expat officials and important European visitors. For the former the style of hospitality was implicitly part of the 'civilising mission' and part preparation for the devolution of responsibilities. For the latter such social rituals generated group cohesion and were a reminder of the 'civilised' standards to which they should adhere.

Such occasions also had serious administrative and political purposes. They were opportunities for governors to meet, educate, encourage, appraise and perhaps learn from subordinates; to consult and inform distinguished (or at least self-important) visitors; to discuss the schemes floated by locally-based or visiting overseas businessmen; and increasingly with constitutional developments in mind to establish and sustain working relationships with local people upon whom responsibilities would in due course be devolved. ${ }^{84}$ For example, such occasions would be used by the Fields to sound out opinion about the future of the Southern Cameroons and the anticipated consequences of its inclusion inside an independent Nigeria or its merger with its French other half into a federal republic of the Cameroons. Lavish cocktail parties, dances and dinners at Plantation House on St Helena were intended to erode spaces between government and governed and to encourage involvement in democratic politics. In Montserrat, constructive relationships with the chief minister, administrative officers, islanders and visitors might be created over dinner or cocktails, and similarly in Tarawa in the Gilberts, where anxieties about constitutional changes and economic developments might be eased by invitations to attend social occasions hosted by the governor and his wife. In the late Colonial Empire, by contrast with how it may have been previously, eroding rather than maintaining social distance between rulers and ruled was the aim. ${ }^{85}$

These occasions were extraordinarily frequent. St Helena may seem just a dot in the south Atlantic, not easy to access, and with a resident population barely over 4000, but dinner guests (excluding those staying overnight) totalled 6175 between May 1962 and December 1967, a still more staggering total when it is recognised that during this period the governor and his wife spent time also in Ascension and in two of those years they were away on leave for months at a time. ${ }^{86}$ Even in the mid-Pacific, government house under Lady Field's management heaved with guests. The Fields hosted 190 functions in their Tarawa home between their arrival in January 1970 and their departure in April 1973. ${ }^{87}$ In 1970 alone, 45 overnight guests stayed a total of 124 nights, 324 others came for lunch or dinner, 61 people stayed for tea, and over 1200 attended their cocktail parties. On the Queen's Birthday in June 1971, 350 people attended the garden party (and similarly in June 1972), and on 14 December 1971 the Fields hosted a dinner party for 24 followed by a cocktail party for 264 . Among the guests with whom Lady Field had to cope was the Prince of Wales and his entourage in October 1970 - involving also the preparation of a reception for 400 people. In March 1972 she wrote wearily of 'the everlasting struggle to keep up with the entertaining'. By the end of that year, house guests had numbered over 50 (staying 168 nights), and at least 475 had been guests for lunch or dinner, 226 for afternoon tea and 982 for cocktails. ${ }^{88}$ 
Because of her as well as his gendered expectations it largely fell to Margaret Field to organise such occasions, and the first requirement was to construct as an exemplar of 'civilised' standards the domestic space in which such political theatre could be successfully performed. ${ }^{89}$ As presented in letters to family at the time and put on the record in her memoirs, this was a challenge she relished and from which she distilled satisfaction. No doubt her Hampstead Garden Suburb upbringing had set certain standards. Even as a single woman teaching in Birnin Kebbi she had written home vividly about how she had turned her government-provided house (a hut) into a home, and that had been repeated when she first moved to a flat in Lagos. ${ }^{90}$ In part of course the domestication of space was about maintaining, in the face of what a white middle-class woman would find alien and even threatening in a tropical African environment, the genteel standards which in her upbringing she had absorbed and which to sustain her self-respect had to be invested in her home in Africa. ${ }^{91}$ Hence her preoccupation with interior furnishing and gardens. Achievement is also written into her descriptions of the succession of homes she subsequently created elsewhere in Nigeria. ${ }^{92}$ These venues were of course places in which colleagues and visitors were entertained, but Margaret Field's obligation to provide hospitality more substantially and more frequently increased considerably when she became sequentially chatelaine of four government houses - in Buea in the Southern Cameroons, on the island of St Helena, in Montserrat, and at Tarawa in the Gilbert Islands - four properties each in need of 'improvement' in order to meet her exacting standards and make them fit to stage the politics of gubernatorial hospitality. ${ }^{93}$

She was astonished by her good fortune in becoming in Buea not just the lady of the house but the lady of the Schloss, for the Commissioner's residence in this former German colony had been built in grand style and set in an extensive garden. Even so, Margaret Field set to work to renovate and improve, making it fit for purpose, not just as her home but as a setting for politically-charged hospitality. Hence to impress visitors (and satisfy her own love of gardening) the close attention she paid to redesigning, planting and tending the gardens, creating additional bedrooms and staff offices, upgrading the plumbing, repainting interiors, choosing carpets, curtains, pictures and ornaments, refurnishing rooms, and adding the dining room table which her husband (no mean craftsman) designed so that it could host intimate dinner parties of four and be magnificently extended to seat up to twenty. Larger parties were accommodated in the main hall and upper landing, and, of course, in the gardens. All this she recorded in her memoirs, and by the taking of photographs. ${ }^{94}$ Indeed, such was her enthusiasm for this setting that she researched and published a history and description of the house. ${ }^{95}$ She also wrote a similar text about Plantation House on St Helena, ${ }^{96}$ but this was a property whose external grandeur concealed internally a host of challenges to make it, for Lady Field, fit for purpose. Not only did the house need redecorating, the chairs reupholstering, the soft furniture replacing, and the carpets and curtains replacing (her predecessor's taste filled her with the horrors), but the kitchen, plumbing and electricity demanded serious upgrading. What was needed, in her estimation, required far more than the grudging expenses allowance provided by the Colonial Office. And the garden, as at Buea, needed to provide not just a setting for garden parties but cut flowers to be tastefully arranged as decoration inside the house, especially to impress guests of whom as noted there were lots. ${ }^{97}$ Government House in Montserrat was, it seems, a poorly furnished and uncomfortable Victorian villa (without air-conditioning) with a potentially attractive but unkempt garden, which Lady Field addressed with cosmetic improvements but otherwise grudgingly tolerated because of Sir John's temporary tenure of office as Acting Administrator. ${ }^{98}$ However, the residency in Tarawa, with a garden, close to a white sand beach and a blue lagoon, and 
adjacent to the rich foliage of a Pacific island, provided not just a home but a hospitality setting which, with her husband's assistance, Lady Field with relish set out to improve. Rooms were added, decoration embellished, mains services upgraded, the garden extended. ${ }^{99}$

A house, Le Corbusier wrote, is a machine for living in, but getting the machine to work efficiently in the way expected of governors' wives was as much about staffing as plumbing. According to Kirk-Greene, household staff at a Government House might number up to $40 .{ }^{100}$ Managing the staff was a gendered responsibility. As noted earlier, servants at home were part of Margaret Judd's upbringing, but it was also an assumption among those recruited into the Colonial Service and expat residents in business and the professions that they would employ local servants as housekeepers, cooks, gardeners, grooms or in other capacities, in Africa mainly men, or 'boys' in that infantilising colonial parlance. ${ }^{101}$ Certainly Margaret Judd as a professional single woman in Nigeria had servants from the outset, and indeed in the person of Robinson Akugwhara Iweala (his name she reverently recorded in full in her memoirs, otherwise referred to just as Robinson) she acquired such a highly competent and loyal housekeeper that she retained his services until after twenty-two years and to the distress of both they parted, when her career with John Field took her away from Africa. ${ }^{102}$

She states in her memoirs that she had found the recruiting and training of other domestic staff in Nigeria and the Cameroons a trial, ${ }^{103}$ but she records especially her struggle in St Helena to find, train and keep the indoor and outdoor staff needed to provide the standard of service she demanded not just for herself and her husband but for overnight visitors and the thousands attending the events at Plantation House which Sir John and Lady Field, and especially she, were committed to providing, and providing well. By her account, the housekeeper failed to exercise proper authority over the other staff, the cook was very good but noisy and temperamental, some of the youngsters were undisciplined, the gardener resented her intervention in what he regarded as his domain, and standards could slip without her close supervision. ${ }^{104}$ We do not of course hear their voices in her records. If anything, the staff in Montserrat she reported as worse, ${ }^{105}$ while those in Tarawa, 'charming but imperfect', needed training. ${ }^{106}$ The difficulty of securing, training and retaining good local staff (at low wages) was a matter that crops up repeatedly in the memoirs of expat wives and working women in British colonies, but it was especially seen as a challenge by governors' wives upon whom rested the obligation to provide hospitality publicly, on a large scale, and very frequently. ${ }^{107}$

It would have been easier if food supplies were always readily available. This too was a challenge devolved on wives. In West Africa local markets and stores supplied by trading companies generally provided what was needed, but nevertheless catering for large numbers in Buea remained a trial. ${ }^{108}$ But the rundown in the number of smallholdings in St Helena, limited produce from the Plantation House garden, a climate which erratically generated droughts or floods, and long waits between the arrival of ships supplying goods from the UK and the Cape considerably increased the stress on a governor's wife whose political duties as well as self-respect were dependent on providing a good spread for many people. The eventual arrival and installation of a deep freeze (and a washing machine) made feeding the thousands a little less of a conjuring trick, though it sometimes still involved Governor Field going out fishing to add stock to the freezer. ${ }^{109}$ Lady Field found food supplies even in the Caribbean island of Montserrat dismayingly limited, ${ }^{110}$ but on Tarawa in the Gilberts, securing supplies, especially of meat (and drink), required near military planning by her literally months in advance, so infrequently did supply ships arrive with ordered provisions, and crises occurred when promised arrivals were delayed, sometimes by weeks. Yet again 
Sir John was sent out fishing. ${ }^{111}$ Another obligation, of course, was to ensure that suitable meals were prepared, entailing, in her case, poring over the pages of Constance Spry's cookery book, carefully ensuring that her kitchen staff understood and followed the recipes (as well as herself sometimes preparing dishes), and keeping records of dinner menus to avoid the social faux pas of serving up the same dish to the same guests on another occasion. ${ }^{112}$ Since Margaret Field accepted that the politics of government and not just the conventional western gendering of domestic responsibilities required the consistent provision by her of high quality hospitality in a delightful and well-managed setting, it is not surprising that, in her diaries, she recorded her worries before the event, her relief afterwards when all went well, and her anxieties about the next and too often imminent occasion. But in her memoirs these are challenges overcome.

Since on display was herself, Lady Field was very conscious of her appearance. Dress mattered. This may not have been entirely a gendered anxiety, but such references occur in her diaries and not in those of her husband. Clothes tailored in both senses for the occasions were as much her uniform as the dinner jacket or full governor's rig worn by her husband. The message being sent out to observers by her smart appearance was that she, like the wives of other senior Colonial Service officials, was preserving and exemplifying British standards, including among the European community, in a challenging colonial world. Too often unthinkingly satirised, dressing formally for dinner even in tropical climates was also part of the politics of empire, intended in this instance to maintain the morale and self-respect of the wearer, even without an audience. The older generation may have insisted that not wearing corsets was 'demoralizing' and a 'huge mistake', ${ }^{113}$ but appropriate dress was still assumed to be necessary to maintain genteel standards within a household populated with locally-hired servants in which privacy was hard to secure, and still more so when Lady Margaret, the governor's wife, like Sir John as governor, publicly represented the Crown and British rule, a responsibility of which she was well aware: it was, she wrote, important 'to dress and act the part'. ${ }^{114}$ Buying suitable clothes in Cape Town and in London when on leave and even by mail order was a serious business. Finding skilled dressmakers in under-resourced St Helena and Tarawa was an unexpected blessing. ${ }^{115}$

It was also expected of her and she expected of herself to engage even more in 'good works'. Ostensibly intended to ease the difficulties of the 'deserving poor', such activities had long been characteristic in the UK of women of the same social class as Margaret Field who were not otherwise in paid employment (and often even then). But the exercise of authority in colonial societies generated additional distinctions between expat officials and subordinate local people, which in late empire added a further motive for charitable activities across the divide by expat wives - though it seems this was not an objective recognised by married women in British India. ${ }^{116}$ The 'good works' which Margaret Field and the wives of other governors undertook were implicitly concerned with 'good government' and the public exercise of soft power. They were to that extent as political as anything done by their husbands.

Sometimes she and Sir John operated as a team, the governor and his wife, for example when at Christmas in St Helena they visited the poor house, general hospital and mental hospital, and similarly in Tarawa, where they were also both patrons of the Family Planning Association. But Lady Field, like other governors' wives, also and alone took initiatives and accepted leadership responsibilities. On St Helena she dropped in on the housebound and on impoverished families in isolated parts of the island and left them gifts. She invited the elderly and patients from the mental hospital to take tea with her and walk in the grounds of 
Plantation House. ${ }^{117}$ Seemingly ex officio she was also involved in the Women's Institute and ran the local branches of the Women's Corona Society. By providing a meeting place for all expat wives, the WCS aimed to ease the loneliness and also the debilitating effect on the morale of 'junior' women in the hierarchical order which colonial government inevitably imposed even upon the European community. But membership had also been opened up to local women too, an innovation in Nigeria and later in Southern Cameroons which Margaret Field had herself endorsed, and in the latter days of empire this also carried a political charge, reducing the gap between governors and governed. Furthermore, the local branches functioned as fund-raising agencies, distributing charity to deserving locals. Her revival of the St Helena branch and the 'good works' it organised were one of her activities during her six years on the island in which she took particular pride (and Sir John in her), and she was similarly successful in reactivating the Tarawa branch. ${ }^{118}$ She was also committed ex officio to Red Cross activities, which she enjoyed, ${ }^{119}$ and to the Girl Guides movement, which she did not. Prejudiced by her own miserable experiences as a youngster, she became reluctantly involved with the Guides in the Cameroons, but she particularly deplored her obligations to the movement on St Helena because of squabbling within the organisation, which not even her authority as the governor's wife could resolve. ${ }^{120}$ Nevertheless, and also by attending sports days when she was obliged to hand out prizes, she was by her presence endorsing the value and legitimacy of disciplined youth movements and these imported forms of Britishness. ${ }^{121}$ Her important but subordinate role was also evident when she accompanied Sir John on some pretty arduous trips around the Gilbert and Ellice Islands Colony. At each island a programme of visits was drawn up specifically for Lady Field, visiting schools, as mentioned earlier, and addressing local women's groups and subsequently trying to satisfy local requests for advice and equipment. ${ }^{122}$

$\mathbf{V}$

What the careers of Miss Margaret Judd and her unmarried contemporaries confirm, particularly as depicted in memoirs, is that Britain's Colonial Empire provided a substantial and latterly an increasing number of single women with career opportunities which carried for them a high moral weighting. We also know that these jobs were gendered, most of those women being recruited into what were generally understood to be female professions - as nurses or as teachers in schools for girls, plus some as secretaries and only a few, latterly, as senior administrators. Other life histories too suggest that women recruited into the Colonial Service and later HMCOS, plus women missionaries, particularly those involved in education and the medical professions, aimed to effect what they regarded as beneficial changes in local cultures and in the lives of local women, by their example, by the training provided, and by encouraging the formation of women's groups. ${ }^{123}$ Whether this unwittingly or intentionally accelerated the demand for political liberation seems still to be a moot point, but more certainly some local women were able thereafter to take on responsibilities when the ending of empire arrived. We have also been alerted to a number of expat single women who 'stayed on' and continued to work with and for the betterment of women in post-empire communities. ${ }^{124}$

However, we also know that many of the careers of single British women working in empire ended with marriage, commonly to men in the Colonial Service. Miss Judd's career fits the pattern, a school teacher and college principal who became a senior educational administrator, but whose independent career ended when she married. Lady Field, incorporated as a wife and eventually as the consort of a governor, admitted that on a personal level it had been difficult to settle happily into married life after 'having always 
been a career girl', and she 'felt the lack of some work badly' and 'a position of my own right'. ${ }^{125}$ At bleak moments she recorded her dismay at the narrowing of her life, her lack of satisfying occupations while her husband was working and often away from home, and her fear that she might 'degenerate into a mere housewife,' or, as she frequently put it, become just a 'Martha' when she aspired to be a 'Mary'. ${ }^{126}$ The 'ennui' to which she referred in her diaries was caused, paradoxically, sometimes by having too little to do but often by being too exhausted by her duties to find and engage in activities personally more satisfying. She felt over-worked but under-employed. 'One needs work, occupation, a raison d'être. One is very dull and dead when one's faculties are not being used'. ${ }^{127}$ Later, when Sir John was briefly based in London, she again sought (though did not obtain) a part-time job, 'for sake of outside interest and using my "talents", to 'use my mind, and ... not be just a housewife'. ${ }^{128}$

There were of course women married to senior Colonial Service officers who in memoirs and recorded testimony reported satisfaction and personal development in their supportive roles, and some lower in the colonial hierarchy even retained a degree of personal agency by securing paid employment (if only to supplement family income) and by independent involvement in voluntary activities. ${ }^{129}$ But others confessed their dissatisfactions with their allocated roles, and some that by marriage they had sacrificed a rewarding career. In May 1971, Margaret, Lady Field, had a conversation with Marjorie, Lady Bodilly, wife of Chief Justice Sir Jocelyn Bodilly. They knew each other because Tarawa was part of his South Pacific circuit. In her diary Lady Field commented that Lady Bodilly had been a senior physiotherapist in Hong Kong, but since her 'rather late marriage' she had been unable to practise her profession, and now she 'finds life just as a wife in some ways boring and aimless'. Lady Field sympathised. ${ }^{130}$ Nor was Lady Field alone in feeling constrained by her role as a governor's wife. Indeed, her successor in the Gilbert and Ellice Islands, another former teacher, recorded how she 'escaped' to the local school for the 'odd half hour' and 'enjoyed immensely' helping children with reading problems. Similarly, another universityeducated former teacher who became a governor's wife recorded that 'I envy women who have been able to combine marriage with a successful career of their own which was impossible in either the Colonial or Diplomatic services'. ${ }^{131}$

However, Lady Field had made what she regarded at the time and in retrospect her own positive contribution to the cause of empire, first as a single woman and then as a governor's wife. In her memoirs she acknowledged her good fortune in marrying a man she loved, and she relished her rise in status and the opportunities and rewards it brought. More importantly, we also know from her archived records that in spite of the labour involved she understood the importance of her delegated duties, accepted the challenges they presented, and was pleased by the compliments she received. At no point in her diaries or memoirs did she doubt the legitimacy and moral value of her work. Indeed, in a largely conventional retrospective defence of empire by the wife of a senior official, she devotes an entire chapter in her memoirs to insisting that colonial government policies were benevolent, that she had no recollection of 'exploitation', that the 'so-called' Enugu massacre was a 'misjudgement' by a police officer (twenty-one African coalminers had been killed during a labour dispute), that the aim of post-war policy was decolonisation, though in Nigeria it came too quickly, and that 'as for "racism" there wasn't any to speak of'. ${ }^{132}$

This essay has acknowledged that by marriage Margaret Field and the wives of other senior officers had largely lost their independence and become incorporated into the lives of their husbands. She accepted with some regrets that her obligations were indeed to be supportive of John Field, as he had indeed made clear before they married. ${ }^{133}$ But it would be a mistake 
to marginalise such women, and that is not generally how Lady Field represents herself. The duties of governors' wives, though subordinate to their husbands and construed as feminine, were important, demanding and also essentially political, and this warrants recognition. Margaret Judd, as an independent career woman, and Lady Field, as a governor's wife, were as one in the certainty, shared with almost all others in the Colonial Service, that the mission of empire was constructive and legitimate and this therefore validated her entire career, at the time and retrospectively.

\section{References}

Adams, Melinda. 'Colonial policies and Women's participation in public life: the case of British Southern Cameroons'. African Studies Quarterly, vol.8, no.3, 2006, pp.1-22.

Alexander, Joan. Voices and Echoes: Tales from Colonial Women. London: Quartet Books, 1983.

Allen, Charles (ed.). Tales from the Dark Continent. London: Deutsch and BBC, 1979.

Barringer, Terry (ed.). Administering Empire: an annotated checklist of personal memoirs and related studies. University of London: Institute of Commonwealth Studies, https://static1.squarespace.com/static/545a147ce4b042d9849bcd29/t/598301c8d482e9 5c376b2a20/1501757904173/Administering+Empire+Database.pdf

Boyle, Laura. Diary of a Colonial Officer's Wife. Oxford: Alden Press, 1968.

Bradley, Emily. Dearest Priscilla: Letters to the Wife of a Colonial Civil Servant. London: Max Parrish, 1950.

Brown, Rosemary. 'The Women's Corona Society on St Helena'. St Helena Connection, no 8, May 2010, p.7.

Callan, Hilary and Shirley Ardener (eds). The Incorporated Wife. London: Croom Helm, 1984.

Callaway, Helen. Gender, Culture and Empire: European Women in Colonial Nigeria. London: Macmillan, 1987.

Chaudhuri, Nupur, and Margaret Strobel (eds). Western Women and Imperialism: Complicity and Resistance. Bloomington and Indianapolis: Indiana University Press, 1992.

Constantine, Stephen. 'Governor Sir John Field in St Helena: democratic reform in a small British Colony, 1962-68'. Journal of Imperial and Commonwealth History, vol.44, no.4, 2016, pp.672-96.

Cordon, Roddy. Seven Years' Island Hopping. Lincoln: Cordon and Wood, vol 1, 1996, vol 2, 1998.

Crosskey, Peggy. Knotted Round My Heart: Recollections of Life in Nigeria 1952-59. Grantham: Barny Books, 2007.

Dalton, Heather. The Gold Coast: The Wives' Experience. Oxford: Rhodes House Library, 1985. 
Dalton, Heather. 'The Colonial Service: the Experience of Governors' Wives'. Bodleian Library, Oxford, Mss.Brit.Emp.s.529, 1989.

Davidson, Ann. The Real Paradise: Memories of Africa 1950-1963. Durham: Pentland Press, 1993.

Evans, Dorothy. Schooling in the South Atlantic Islands 1661-1992. Oswestry: Anthony Nelson, 1994.

Field, Margaret. The History of Plantation House and Gardens, 1673-1967, St Helena. Penzance: Patten Press, 1998.

Finch, Janet. Married to the Job: Wives' Incorporation in Men's Work. London: Allen and Unwin, 1983.

Formes, Malia B. 'Beyond complicity versus resistance: recent work on gender and European imperialism'. Journal of Social History, vol.28, no.3, 1995, pp.629-41.

Gartrell, Beverley. 'Colonial wives: villains or victims?', in Hilary Callan and Shirley Ardener (eds), The Incorporated Wife, London: Croom Helm, 1984, pp.165-85.

Halsey, A.H. (ed.). British Social Trends since 1900. Basingstoke: Macmillan, 1988.

Hansen, Karen Tranberg. 'White women in a changing world', in Nupur Chaudhuri and Margaret Strobel (eds), Western Women and Imperialism. Bloomington and Indianapolis: Indiana University Press, 1992, pp.247-68.

Holden, Pat. Women Administrative Officers in Colonial Africa, 1944-1960. Oxford: Rhodes House Library, 1985.

Holden, Pat. Nursing Sisters in Nigeria, Uganda, Tanganyika, 1929-1978. Oxford: Rhodes House Library, 1986.

Hyam, Ronald. Empire and Sexuality: the British Experience. Manchester: Manchester University Press, 1990.

Jeffries, Sir Charles. Partners for Progress: the Men and Women of the Colonial Service. London: Harrap, 1949.

Kirk-Greene, Anthony. 'On governorships and governors in British Africa', in L.H.Gann and Peter Duignan (eds), African Proconsuls: European Governors in Africa. New York and London: The Free Press and Collier Macmillan, 1978, pp.209-64.

Kirk-Greene, Anthony. On Crown Service: a History of HM Colonial and Overseas Civil Services, 1837-1997. London: Tauris, 1999.

Kirk-Greene, Anthony. Britain's Imperial Administrators, 1858-1966. Houndmills: Macmillan, 2000.

Knox-Mawer, June. Tales from Paradise: Memories of the British in the South Pacific. London: BBC, 1986. 
Larymore, Constance Belcher. A Resident's Wife in Nigeria. Memphis: General Books, 2010 ( $1^{\text {st }}$ ed. 1906).

Lawrence, Dianne. Genteel Women: Empire and Domestic Material Culture, 1840-1910. Manchester: Manchester University Press, 2012.

Leith-Ross, Sylvia. Stepping Stones: Memoirs of Colonial Nigeria, 1907-1960. London: Peter Owen, 1983.

Macdonald, Barrie. Cinderellas of the Empire: Towards a History of Kiribati and Tuvalu. University of the South Pacific: Institute of Pacific Studies, 2001 (1 ${ }^{\text {st }} e d$ 1982).

Mangan, J.A. The Games Ethic and Imperialism. Harmondsworth: Viking, 1985.

McIntyre, W.David. Winding Up the British Empire in the Pacific. Oxford: Oxford University Press, 2014.

Midgley, Clare (ed). Gender and Imperialism. Manchester: Manchester University Press, 1998.

Milne, Malcolm. No Telephone to Heaven. Stockbridge: Meon Hill Press, 1999.

Musgrove, Frank. The Migratory Elite. London: Heinemann, 1963.

OSPA. The Role and Experiences of Expatriate Women in the Last Phase of Empire and After. London: Institute of Commonwealth Studies, 2016.

Page, Gwendoline. Coconuts and Coral. Norfolk: Reeve, 1993.

Pearce, R.D. 'Violet Bourdillon: colonial governor's wife'. African Affairs, vol.82, no.327, 1983, pp.267-77.

Procida, Mary A. Married to the Empire: Gender Politics and Imperialism in India, 18831947. Manchester: Manchester University Press, 2002.

Ramusack, Barbara N. 'Cultural missionaries, material imperialists, feminist allies: British women activists in India, 1865-1945', in Nupur Chaudhuri and Margaret Strobel (eds), Western Women and Imperialism, Bloomington and Indianapolis: Indiana University Press, 1992.

Reardon, Margaret. An Unexpected Journey. Life in the Colonies at Empire's End: a Woman's Role. Bourn: Catherine Armstrong, 2015.

Russell, Elnor. Bush Life in Nigeria. Yeovil: Abbey House, 1978.

Sharwood-Smith, Joan. Diary of a Colonial Wife, an African Experience. London: Radcliffe Press, 1992.

Smith, John. An Island in the Autumn. Kinloss, Morayshire: Librario Publishing, 2011.

Strobel, Margaret. European Women and the Second British Empire. Bloomington and Indianapolis: Indiana University Press, 1991. 
Swaisland, Cecille. Forty Years of Service: The Women's Corona Society, 1950-1990. London: Women's Corona Society, 1992.

Symonds, Richard. 'Fraser, Alexander Garden, 1873-1962', Oxford Dictionary of National Biography, 2004-16.

Tripp, Aili Mari. 'A new look at colonial women: British teachers and activists in Uganda, 1898-1962'. Canadian Journal of African Studies, vol.38, no.1, 2004, pp.123-56.

Vickery, Amanda. 'Golden age to separate spheres? A review of the categories and chronology of English women's history'. Historical Journal, vol.36, no.2, 1993, pp.383-414.

Whitehead, Clive. 'The medium of instruction in British colonial education: a case of cultural imperialism or enlightened paternalism?' History of Education, vol.24, no.1, 1995, pp.1-15.

Whitehead, Clive. Colonial Educators: the British Indian and Colonial Education Service 1858-1983. London: Tauris, 2003.

Whitehead, Clive. 'Gwilliam, Freda Howitt, 1907-1987', Oxford Dictionary of National Biography, 2004-16.

Winkler, Stephen. 'Vischer, Sir Hanns, 1876-1945', Oxford Dictionary of National Biography, 2004-16.

\footnotetext{
${ }^{1}$ Early historiographical landmarks include Gartrell, 'Colonial wives'; Callaway, Gender; Strobel, European Women; Chaudhuri and Strobel (eds), Western Women and Imperialism. For an appraisal of the literature see Formes, 'Beyond Complicity'.

${ }^{2}$ It has been strongly argued that wives in British India were able to enjoy experiences and express values more commonly associated with men and masculinity: Procida, Married to the Empire, and perhaps note especially the chapter on guns and hunting.

${ }^{3}$ Pioneering here is Callaway, Gender.

${ }^{4}$ Tripp, 'British teachers and activists'; and, more cautiously, Adams, 'Colonial policies and women's participation'.

${ }^{5}$ On the concept and its application see Callan and Ardener (eds), Incorporated Wife, and Finch, Married to the Job. For a critique of the stereotype and the quotation which follows see Procida, Married to the Empire, pp.1-7, 11, and also Callaway, Gender, pp.3-8.
}

${ }^{6}$ Strictly speaking, Margaret Field was only a 'Governor's wife' 1962-8 and 1972-3, but she had equivalent status and roles when John Field's titles were Commissioner and Administrator. She became Lady Field when he was made a Knight Bachelor (Kt) of the British Empire in 1962, elevated to Knight Commander (KBE) in 1967. He had already become in 1959 a Companion of the Order of St Michael and St George (CMG). 
${ }^{7}$ The recent book by Prior, Exporting Empire, dealing with an early period in the history of the Colonial Service, 1900-39, only refers to women as wives of officials and to what some Colonial Service men resented as their disruptive presence, pp.82-3.

${ }^{8}$ Jeffries, Partners in Progress, pp.152-3.

${ }^{9}$ Kirk-Greene, On Crown Service, pp.49-53, 74.

${ }^{10}$ Jeffries, Partners in Progress, pp.155-6.

${ }^{11}$ Barringer (ed.), Administering Empire. A further five publications are edited collections of testimony by women.

${ }^{12}$ Crosskey, Knotted Round My Heart.

${ }^{13}$ The other five wives were Sylvia Foot, Molly Huggins, Margaret Luce, Alys Reece and Joan Scott.

${ }^{14}$ OSPA, Expatriate Women.

${ }^{15}$ Callaway, Gender; Holden, Nursing Sisters; Holden, Women Administrative Officers; Dalton, Wives' Experience; Dalton, 'Governors' Wives'.

${ }^{16}$ Mss.Brit.Emp.s.566.

${ }^{17}$ Henceforth Letters.

${ }^{18}$ Henceforth Diaries.

${ }^{19}$ Henceforth Memoirs.

${ }^{20}$ Henceforth JF Journals.

${ }^{21}$ Diaries, 24 March 1963; and 5 Feb 1953 and Memoirs, p.383, on her 'introspective' use of her diary.

${ }^{22}$ Callaway, Gender, pp.110-17.

${ }^{23}$ See, for example, Memoirs, pp.38-9, and Letters, 10 Jan 1939, reporting a dinner she attended in Birnin Kebbi hosted by Governor Sir Bernard and Lady Bourdillon, followed by their visit to her school, and a reference to John knowing 'all the protocol', Memoirs, p.133.

${ }^{24}$ For a historiographical critique of the term see Vickery, 'Golden age to separate spheres?'

${ }^{25}$ Memoirs, p.1.

${ }^{26}$ Obituary, The Times, 7 Jan 1961, p.10.

${ }^{27}$ References to her publications in The Times, Manchester Guardian, Blackwood's, House and Garden and Christian Science Monitor, using her mother's maiden name as Meg Hoyte, appear frequently in her Memoirs, as well as in her Diaries.

${ }^{28}$ Memoirs, pp.1-12.

${ }^{29}$ Memoirs, pp.2, 142; Diaries, 10 Jan 1939, 28 Aug.1964; JF Journals, 6 Sept 1964.

${ }^{30}$ For examples Holden, Women Administrative Officers, pp.18-37; Holden, Nursing Sisters, pp.11-38; Dalton, Wives' Experience, pp.17-18; Dalton, 'Governors' Wives', p.11.

${ }^{31}$ Obituary in Africa: Journal of the International African Institute, April 1961, vol.31, no.2, p.1.

${ }^{32}$ Symonds, 'Fraser, Alexander Garden, 1873-1962'. 
${ }^{33}$ On which constraint see Callan, 'Introduction' to Callan and Ardener (eds), Incorporated Wife, p.13, and Dalton, 'Governors' Wives', pp.25, 27, 28, 77, and as an example testimony of Lady Paul, p.10.

${ }^{34}$ Memoirs, pp.12-22.

${ }^{35}$ Memoirs, pp.22, 42.

${ }^{36}$ Winkler, 'Vischer, Sir Hanns, 1876-1945'.

${ }^{37}$ Memoirs, pp.1, 22-5.

${ }^{38}$ Letters, 25 Nov 1937-27 Dec 1938; Memoirs, pp.26-67.

${ }^{39}$ For explicit references to love affairs see Letters (to women friends) 22 March and 27 Dec 1938, Memoirs, pp.40,51 89, and Diaries 30 May 1966, and also 21 Sept 1961 where she records the re-reading and then burning of love letters: 'I felt ... half sad and half happy to think how very much I have been loved. And on top of all to be blessed with John'. It would be rash to suggest on the basis of Margaret Judd's correspondence that the Empire overseas presented women with more opportunities to express their sexuality than in the UK, but such cases might qualify the impression of male-only sexual freedoms recorded in Hyam's Empire and Sexuality.

${ }^{40}$ Whitehead, 'Medium of instruction', esp.p.6.

${ }^{41}$ Letters, 30 Nov 1937.

${ }^{42}$ Memoirs, pp.26, 33-5, 47; Whitehead, 'Education in British Colonial Dependencies', p.76.

${ }^{43}$ Letters, 27 Dec 1938. See also Letters, 11 and 18 Jan, 8 Feb 1938, and 10 Jan 1939;

Memoirs, pp.32-5.

${ }^{44}$ On this official objective and problems of implementation in Northern Nigeria see Callaway, Gender, pp.111-23.

${ }^{45}$ Such motives or at least such effects are debated by Tripp, 'British teachers and activists' and Adams, 'Colonial policies and women's participation'.

${ }^{46}$ Whitehead, 'Education in British Colonial Dependencies', pp.77-8.

${ }^{47}$ Letters, 11 Jan, and see 24 April and 31 Oct 1938, and Memoirs, p.46.

${ }^{48}$ Memoirs, pp.50a, 62-65; Callaway, Gender, pp.119-20.

${ }^{49}$ Memoirs, pp.72-5, 79-81.

${ }^{50}$ Letters, 27 Dec 1938.

${ }^{51}$ Memoirs, pp.88-9.

${ }^{52}$ HCPP, Department of Technical Co-operation, Recruitment for Service Overseas: Future Policy, Cmnd 1740, May 1962, pp.14-16, 24. For career experiences in educational administration in Tanganyika see Holden, Women Administrative Officers, pp.87-90.

${ }^{53}$ Memoirs, pp.73-4, 84; Jeffries, Partners for Progress, pp.162-4; Callaway, Gender, pp.114, 127, 241.

${ }^{54}$ Diaries, 31 Dec 1969; Callaway, Gender, pp.115, 142; Whitehead, Colonial Educators, chap 13 'Freda Gwilliam', pp.244-60; Whitehead, 'Gwilliam, Freda Howitt'.

${ }^{55}$ Diaries, 21 March 1971; Memoirs, p.520. 
${ }^{56}$ Her sister Alison, only a couple of years younger than herself, trained and practised as a doctor in the UK, and yet also married and raised a family: Memoirs, p.4.

${ }^{57}$ Halsey (ed.), British Social Trends, pp.165-7; Musgrove, Migratory Elite, pp.41-2.

${ }^{58}$ Callaway, Gender, pp.46-8, writes caustically about this obligation and its consequences.

${ }^{59}$ Holden, Women Administrative Officers, pp.3, 122, 208-11. For wartime employment see Sharwood-Smith, Colonial Wife, pp.30, 34-5, 66-7. On post-war reduction of employment opportunities for wives, Bradley, Dearest Priscilla, pp.167-70. In 1952 a senior officer in Nigeria was allowed to employ his wife as his paid but only temporary secretary: Milne, No Telephone, p.296. But in 1957 the Information Office in Nyasaland hired a universityeducated (but administratively inexperienced) wife: Davidson, Paradise, p.337.

${ }^{60}$ Memoirs, pp.96-8.

${ }^{61}$ Memoirs, pp.152-4: she left with a 'glowing testimonial'.

${ }^{62}$ For example, in St Helena, Diaries, 25 Nov 1962, and Memoirs, pp.375, 439; in Ascension, Diaries, 1 March 1963; in Montserrat, Memoirs, p.154, referring to a report on local schools she submitted to a minister, and JF Journals, 17 Oct 1969; and in the Gilbert and Ellice Islands, Diaries, 15 March, 3 May 1971. The St Helena education officer, who had escorted Lady Field around the island's schools, credited her as well as the governor with supporting his proposals for educational developments: Evans, Schooling, p.152.

${ }^{63}$ Memoirs, pp.247, 383-4, and Diaries for frequent references, the first 8 April 1953 (when she was 47) and the last 24 July 1973 (when she was 68).

${ }^{64}$ Dalton, Wives' Experience, pp.49-50, 58; Dalton, 'Governors' Wives', pp.15, 19, 21, 71-6; Allen (ed.), Dark Continent, p.123; Sharwood-Smith, Colonial Wife, pp.64, 71, 73, 81; Alexander, Voices, pp.38, 40, 60-1, 196-7; Reardon, Unexpected Journey, pp.162-3, 191.

${ }^{65}$ Constantine, 'Sir John Field in St Helena'.

${ }^{66}$ JF Journals. The complexities are analysed in Kirk Greene, Britain's Imperial Administrators, pp.363-7.

${ }^{67}$ JF Journals.

${ }^{68}$ In addition to JF Journals see Macdonald, Cinderellas of the Empire; McIntyre, Winding Up the British Empire in the Pacific, and Smith, Island in the Autumn, a memoir by Field's successor as governor.

${ }^{69}$ Memoirs, p.108A.

${ }^{70}$ Memoirs, pp.252-3.

${ }^{71}$ Diaries, 2 Sept 1969, and see also 12, 13 Aug 1969, 25 Jan, 15 March, 11 Nov 1970.

72 Memoirs, p. 253.

${ }^{73}$ Diaries, 16 Feb, 24 March, 14 April, 19 July 1953, 5 June 1955, 3 June, 2 Aug 1962, 3 May 1965, 4 June 1972; Memoirs, pp.94-5.

${ }^{74}$ The domestic conditions in which a bachelor lived in the Gold Coast were recorded, with dismay, by the wife of his married successor: Boyle, Colonial Officer's Wife, pp.95-6.

${ }^{75}$ For example Dalton, 'Governors' Wives', testimony of Elaine Bernacchi, Lady Haskard, Lady Maddocks and Janet Strong; Pearce, 'Violet Bourdillon', p.271. 
${ }^{76}$ Procida, Married to the Empire, pp.30, 43, 47-51, refers to 'incorporated wives' as 'junior partners' in a 'companionate partnership' unofficially advising and assisting their ICS husbands.

77 The National Archives, Kew [henceforth TNA], FCO44/1549, Duff, internal office note, May 1977. Referring to his successor on St Helena, Field reckoned that not being accompanied by a wife would be 'a drawback in a place like this': JF Journals, 17 Jan 1968.

${ }^{78}$ Memoirs, p.340.

${ }^{79}$ The point is properly stressed by Kirk-Greene, Britain's Imperial Administrators, pp.222-

3. For descriptions of elaborate events in Nigeria, and of appropriate dress, including for women, see Callaway, Gender, pp. 57-63. For a wife's testimony see OSPA, Expatriate Women, p.101.

${ }^{80}$ As examples, on their departure from the Southern Cameroons, arrival at St Helena, commemorating Armistice Day, when on tour in the Pacific, when sworn in as the first Governor of the Gilbert and Ellice Islands, and their final departure: Memoirs, pp.314-5, 3378, 416-7, 471-2, 475, 584-5, 592-3. The importance of ceremonial and precedence is stressed by Kirk-Greene, 'On governorships', pp.227-9.

${ }^{81}$ Dalton, 'Governors' Wives', p.51.

82 TNA, OD8/110, 6 Sept 1961.

${ }^{83}$ Callan, 'Introduction', pp.9-10, Kirk-Greene, 'On governorships', pp.217-8; Procida, Married to the Empire, pp.59-60. For more on 'good hostess' obligations see Dalton, 'Governors' Wives', pp.48-57, and on their importance for race relations, p.62, and wives' testimony.

${ }^{84}$ On the importance of personal contacts with non-official interest groups in the run-up to the transfer of power see Kirk-Greene, Britain's Imperial Administrators, p.230.

${ }^{85}$ Strobel, European Women, pp.9-10, refers to the social rituals of the governing class as a way of maintaining 'social distance between Europeans and indigenous people', but in late empire the reverse was intended. As just one example of what was intended and seemingly effected at a reception hosted in the Cameroons see Memoirs, p.214.

${ }^{86}$ Lady Field Personal Entertainment Book, Vol.VI, last page, Field Papers. For frequency of occasions see the many references in JF Journals.

${ }^{87}$ Calculated from JF Journals.

${ }^{88}$ Memoirs, pp.469, 496-503; Diaries, 1 Nov 1970, 11 Jan, 14 June 1971, 7 March, 12 June, 26 Dec 1972.

${ }^{89}$ This responsibility is echoed in testimony concerning Gladys Drury Adams, the wife of the Resident in Sibu, Sarawak, in the 1930s and 1940s: OSPA, Expatriate Women, p.22.

${ }^{90}$ Letters; Memoirs, p.79.

${ }^{91}$ Conceptually what follows owes much to Lawrence, Genteel Women.

92 Memoirs, pp.109, 148; Diaries, 19 Feb 1953.

93 The varying quality of official residences, and efforts to improve, feature strongly in

Dalton, 'Governors' Wives', pp.29-36. 
${ }^{94}$ Memoirs, pp.176-8, 183, 224, 295; Diaries, 26 July 1956, 30 March, 19 May 1958. Photographs of the Schloss, the gardens, the rooms and the table are in the Field Papers, as also of her other government houses.

${ }^{95}$ Memoirs, p.263; Margaret Field, The Commissioner's Lodge and Gardens, Buea, 1961, reprinted as The Prime Minister's Lodge Buea, Ministry of Primary Education and West Cameroon Antiquities Collection, Field Papers.

${ }^{96}$ David Smallman, governor 1995-99, arranged for publication of her typescript: Field, Plantation House.

${ }^{97}$ Memoirs, pp.367-8; Diaries, 27 May, 8 June, 30 Aug, 7 Oct 1962, 22 July 1963, 26 Nov 1964, 8 March, 21 April, 3 May, 16 Aug 1965, 30 Sept 1967.

${ }^{98}$ Memoirs, p.450; Diaries, 22 June, 12 July, 3 Aug 1969; JF Journals, 29 June, 9 July 1969. A later occupant also criticised Government House in Montserrat: Dalton, 'Governors' Wives', pp.29, 35-6, testimony of Ruth Wyn Jones.

${ }^{99}$ Memoirs, pp.460-2, 465-6, 488, 491-2. Many references to work on the house and garden are in Diaries, for example 15 Jan 1970, 15 March 1971, 5 May 1972; and JF Journals, 23 June, 2 Aug, 30 Sept, 7 Oct 1970, 31 March, 7 June 1971, 13 May, 24 Sept 1972.

${ }^{100}$ Kirk-Greene, Britain's Imperial Administrators, p.221; and on supervision by wives see also Kirk-Greene, 'On governorships', pp.221.

${ }^{101}$ Strobel, European Women, 21-24.

102 Memoirs, pp.60-1, 187, 293, 308-9; Diaries, 28 April, 21 Sept 1961, 29 June 1962.

${ }^{103}$ Memoirs, pp.111, 179-80, 254, 286-7; Diaries, 8 Feb, 6 March 1960.

${ }^{104}$ Memoirs, pp.340-1, 385-6, 422-3; Diaries, for example 3 June, 5 Aug, 25 Nov 1962, 10 April, 16, 17 May, 21 Oct 1963, 5 Jan, 23, 30 July, 6 Sept 1966, 10 June 1967; JF Journals, 19 May 1963, 29 May, 2 June, 12, 27 July 1966, 27 Aug 1967, 6 Jan 1968.

${ }^{105}$ Memoirs, p.450; Diaries, 23 June, 12 July, 12 Aug, 6 Sept 1969; JF Journals, 24 June, 30 July 1969.

106 Memoirs, pp.462-5, 481; Diaries, 11, 15, 25 Jan, 15 March, 15 April 1970, 2 Jan, 5 May, 11 Oct 1972; JF Journals, 10 Feb, 25, 29 July 1970. Lady Field's predecessor had had staffing problems, but her successor described the staff which she inherited as well-trained: Dalton, 'Governors' Wives', testimony of Elaine Bernacchi and Sylvester Smith.

${ }^{107}$ For examples, Dalton, 'Governors' Wives', pp.36-43; Holden, Women Administrative Officers, pp.181-4; Dalton, Wives' Experiences, pp.25-9; Allen, Dark Continent, pp.114-8; Russell, Bush Life, pp.5, 14-6; Leith-Ross, Stepping Stones, p.47; Sharwood-Smith, Diary of a Colonial Wife, pp.103-5; and many references in Reardon, Unexpected Journey. Bradley devotes two chapters of Dearest Priscilla to 'Servants'.

${ }^{108}$ Holden, Women Administrative Officers, pp.184-5; Memoirs, p.181; Diaries, 26 July 1956, 21 June 1961.

${ }^{109}$ Memoirs, 339-40; Diaries, 27 May 1962, 5 Feb 1963, 18 July 1963; 29 Feb 1964, 5 July 1965, 3 Sept 1966, 11 June 1967; JF Journals, 22, 31 Oct, 1 Nov 1962, 24 Dec 1963, 13 March, 19 April, 4 July 1965.

${ }^{110}$ Memoirs, p.453; Diaries, 2, 12 July 1969.

${ }^{111}$ Memoirs, p.467; Diaries, 15, 25 Jan, 15 April 1970, 13, 25 Feb, 15 March 1971, 7 March 1972; JF Journals, 19 Feb 1970; 26 Feb, 1, 15 May 1971; 17 March, 18 July, 18 Aug, 14 Sept 
1972; 3 Feb 1973. See also Dalton, 'Governors' Wives', pp.43-8, and specifically about Tarawa the testimony of Elaine Bernacchi and Sylvester Smith.

112 In 'Entertainment Books', Field Papers, Margaret Field recorded names and numbers of guests, menus and comments on the quality of the courses. When a single woman, she had taken a course on cooking run by the Good Housekeeping Institute: Memoirs, pp.93-4. The Constance Spry Cookery Book was first published in 1956. Other Colonial Service wives seem to have relied on such as Sylvia Leith Ross, Practical West African Cookery (1908) and Emily Bradley, A Household Book for Africa (1939).

${ }^{113}$ Larymore, Resident's Wife in Nigeria; but see also Bradley's tongue-in-cheek warning against the 'Sad Story of the Slut', Dearest Priscilla, p.37.

${ }^{114}$ Memoirs, pp.201, 225, 493, 566; Diaries, 30 March 1958, and similarly 19 Oct 1962, 2 March, 30 May, 31 Oct 1963, 4 Aug 1964. On the importance of dress within imperial culture in the colonies see Lawrence, Genteel Women, pp.12-72; Strobel, European Women, pp.10-11; Callaway, Gender, pp.71-5; Holden, Women Administrative Officers, p.197, and as examples Knox-Mawer, Tales from Paradise, pp.33, 35, 42, and Russell, Bush Life, 17.

115 Diaries, 1 Nov 1966, 9 June 1967, 15 March 1971.

${ }^{116}$ References to 'good works' are common in the sources. Dalton, 'Governors' Wives', pp.66-9, and as examples testimony of Lady Arthur, p.11; Holden, Women Administrative Officers, p.193; Dalton, Wives' Experience, pp.51-2; OSPA, Expatriate Women, pp. 15, 30, 85, 100; Boyle, Diary, p.162; Sharwood-Smith, Colonial Wife, pp.112-4; Alexander, Voices, pp.68, 123, 89-90; Reardon, Unexpected Journey, pp.143-4, 160; Bradley, Dearest Priscilla, pp.166-7, 170-2; Pearce, 'Violet Bourdillon', pp.268-9. For Anglo-Indian wives in India see Procida, Married to the Empire, pp.165-89, esp.p.171-2.

${ }_{117}$ Memoirs, pp.355-8, 409, 432-3; Diaries, for example 10 Dec 1962, 5 Feb 1963, 12 Dec 1964, 4 March 1965, 3 Sept 1966, 16 June 1967.

118 Memoirs, pp.150-2, 356-7, 482; Diaries, 20 March 1968; and see for example 10 Dec 1962, 17 Oct 1963, 13 Aug 1965, 1, 3 Nov 1966, 29 Dec 1967, 24 Jan 1971, 9 Jan, 5 Feb 1972; JF Journals, 15 Dec 1965; 12 April 1973; Swaisland, Forty Years, p.14; Brown, 'Women's Corona Society', p.7; Adams, 'Colonial policies and women's participation', pp.11-12.

${ }^{119}$ Memoirs, pp.356, 481-2, 560; Diaries, for example 25 Jan 1970, 13 Feb 1971, 25 Oct 1972.

${ }^{120}$ Memoirs, pp.356, 442, 482, 578; Diaries, for example 20 July 1962, 10 April 1963, 22 Jan 1965, 13 March 1968, 25 Jan 1970, 2 Dec 1972. For enthusiastic involvement see Alexander, Voices, pp.89-90, and Page, Coconuts, pp.167-9.

${ }^{121}$ Memoirs, p.418; Diaries, 1 Jan 1965; Mangan, Games Ethic.

122 Diaries, Touring Programme notes 27 Jan-6 Feb 1970, 27 April-4 May 1971, 8-18 Feb 1972, 6-16 July 1972.

${ }^{123}$ Cordon, Seven Years' Island Hopping, are the two-volume memoirs of a widow who served as the women's education officer in the Gilbert and Ellice Islands in the 1960s and early 1970s. She refers extensively to her own work in support of women's groups but also, vol.2, p.157, to an 'excellent opening speech' made by Lady Field at a Homemakers Conference.

${ }^{124}$ Joanna Lewis, keynote address, OSPA, Expatriate Women, p.9. 
${ }^{125}$ Memoirs, p.94 and Diaries, 8 Jan 1966, and also 19 Feb 1953, 16 Jan 1955.

${ }^{126}$ Diaries, 17 May, 19 July 1953, 4, 16 Jan, 7 May 1955, 25 March 1961, 3 Jan 1964, 5 Dec 1967, 11 Jan 1971. For Martha and Mary see Luke, chap 10, verses 38-42.

${ }^{127}$ Diaries, 30 May 1966; Memoirs, p.420.

${ }^{128}$ Diaries, 17, 28 March, 23 April 1969.

${ }^{129}$ Dalton, 'Governors' Wives', pp.77-81; Dalton, 'Wives' Experience, pp.50-1; Callaway, Gender, pp.212-4, 222-4; Hansen, 'White women', pp.252-6.

${ }^{130}$ Diaries, 20 May 1971.

${ }^{131}$ Dalton, 'Governors' Wives', p.81, and testimonies of Sylvester Smith, cassette recording, and Janet Strong, p.39.

${ }^{132}$ Memoirs, pp.140-7.

${ }^{133}$ Diaries, 24 March 1953. 